\title{
TRI HITA KARANA AS A MODERATING VARIABLE OF GOOD CORPORATE GOVERNANCE AND CROSSED CREDITS IN FINANCIAL PERFORMANCE OF RURAL CREDIT INSTITUTION OF GIANYAR DISTRICT, INDONESIA
}

\author{
Yuliantari Pande Putu Ida*, Budiasih I G.A.N., Ratnadi Ni Made Dwi, \\ Putra I Nyoman Wijana Asmara \\ Faculty of Economics and Business, University of Udayana, Denpasar, Indonesia \\ *E-mail: idaantari858@yahoo.co.id
}

\begin{abstract}
This study aims to determine how Tri Hita Karana moderates the effect of Good Corporate Governance and Bad Credit on Financial Performance of the Rural Credit Institution in Gianyar Regency. The population in this study is all Rural Credit Institutions (LPDs) that are still operating in Gianyar Regency, as many as 270 populations. The sampling technique uses proportionate stratified random sampling method using the Slovin formula to get the results of 73 research samples. The data analysis technique used is multiple linear regression with Moderated Regression Analysis (MRA). This study found that GCG had a positive effect on LPD financial performance in Gianyar Regency, Bad Credit had a negative effect on LPD financial performance in Gianyar District, and THK weakened the influence of GCG and bad credit on financial performance in LPD of Gianyar Regency.
\end{abstract}

\section{KEY WORDS}

Tri Hita Karana, good corporate governance, loan loss, financial performance, Agency Theory.

Rural Credit Institutions (LPDs), in achieving success, still relies on credit as the main income in financing its operations. Lending is the most important activity of financial institutions in generating profits. Likewise in the LPD, in the course of the amount of credit extended to the public, not all loans are categorized as healthy, but among them are loans that have poor quality or bad credit. This bad credit in the banking world is called Non Performing Loans (NPL). Based on data from the Rural Credit Empowerment Institute (LPLPD) of Gianyar Regency, Gianyar Regency is recorded to be the LPD which has the second largest asset and the second largest LPD number in Bali. Based on the last meeting held on May 28, 2013 that discussed the latest LPD regulations and regarding the main problems of LPDs in Gianyar which still existed were recorded as LPDs that were less healthy, unhealthy, and even bad credit. Following are some of the cases that occurred in LPD in Gianyar Regency, namely: (1) The existence of LPD management games is in the realm of unsecured loans, which resulted in the collapse of LPD finances, (2) The cause of many LPDs in Gianyar experiencing problems is an internal problem between LPD management and the benders don't have a good relationship. (3) Confiscation of 29 assets owned by LPD customers because the customer is unable to pay the arrears of credit by carrying out the activities of the problematic LPD credit handling team begins with visiting the houses of credit arrears that have been running up to six times until finally the LPD manager plans to take decisive steps according awig-awig desa (village's traditional rule), (4) The vacant house owned by local residents because they are unable to pay off bad credit within the stipulated period, (5) There is embezzlement of funds carried out by the head of the LPD which resulted in the LPD not being able to operate and suffered a loss of Rp142 million more.

Gianyar Regency, which has now begun to be used as an example in the system of controlling the performance of all LPDs, namely by holding regular meetings every year, there are still LPDs that are recorded as being unwell. So that doubts begin to emerge with how governance is applied from the LPD itself. With a record of the LPD as a non-bank financial institution that has a very large role in supporting the needs of the village, the LPD 
should have established and applied GCG principles to improve and maintain the performance of financial institutions.

One of the LPD of the Desa Adat (Traditional Village) in Gianyar Regency is that one of them is expected to be able to move the economy of the village community, which is related to the culture of Tri Hita Karana (THK). THK has the concept that harmonious relationships are important in carrying out an activity or organization. The following are some of the important roles that have been applied in the LPD of Gianyar Regency, namely: providing development funds of $20 \%$ of annual profits to custom villages reaching up to Rp 132 million, providing development funds allocated from LPDs of 20 percent given to Desa Pakraman, submit development funds, namely 20 percent of profit with a nominal value of Rp. 313 million, budgeting up to Rp 150 million per year to facilitate piodalan activities in Kahyangan Tiga (Three separate temples for each of the main three Gods) Temple.

Several studies have been conducted on the relationship between GCG and company performance with mixed results. According to Kusumasari (2017), size, transparency, independence, accountability, responsibility and fairness have a positive effect on financial performance. Dwija Putri (2018) conducted research on the effect of good corporate governance and the Tri Hitra Karana Culture on the performance of Rural Credit Banks. The results showed that the application of GCG principles had a positive effect on BPR's financial performance in Bali. In line with that, Krishna Aryastha (2017) also conducted research on the Effect of Good Corporate Governance Principles on Financial Performance of Rural Credit Institutions (LPD) in Denpasar with the results of testing the hypothesis that the principles of Good Corporate Governance have a positive effect on financial performance.

In contrast with some of the studies above, the following results show that GCG has no effect on company performance. Kautsar and Kusumaningrum (2015) and Hartono and Nungrahanti (2014) present evidence that GCG has no influence on company performance. Lady (2016) and Kelana (2015) get the result that GCG has no influence on capital structure, Thuraisingam (2013) also states that there is no significant effect between GCG and company performance as measured by return on assets and return on equity.

Given the inconsistent results of research on the effect of GCG on performance, it is estimated that there are other variables that moderate these effects. The moderating variable considered in this study is the Tri Hita Karana Culture (THK). The relationship between these cultures and their performance was expressed by Riana (2010) and Surya et al. (2014). The use of THK culture as a moderating variable among others has been done by Adiputra (2014) which states that THK culture moderates the influence of task complexity on the internal performance of auditors in the Bali Provincial Inspectorate Office, while Mustikayani and Dwirandra (2016) found that THK culture does not moderate the effect of complexity duty on auditor performance.

THK has the concept that harmonious relationships are important in carrying out an activity or organization. This belief in harmony has become the guidance of the Balinese Hindu community to behave which gives birth to real actions, namely (a) harmony between humans and Ida Sang Hyang Widhi Wasa (God Almighty), known as the Parahyangan, (b) harmony with fellow human beings. Humans are known as Pawongan, and (c) the harmony of human relations with the natural environment, known as the Palemahan.

Financial performance is one measure that can be used by stakeholders to measure or determine the level of company quality. The indicator used in measuring the financial performance of banks including financial institutions is profitability (Siagian, 2011: 51). The profitability ratio that is often used is Return on Assets (ROA). The purpose of this study was to determine the effect of GCG and bad credit on LPD Financial Performance in Gianyar Regency, to find out THK moderates the influence of GCG and bad credit on LPD Financial Performance in Gianyar Regency.

Agency theory considers that company owners can limit differences of interest by establishing appropriate intensities for agents and by incurring monitoring costs designed to limit agent actions. In this case the role of the LPD manager will determine the level of health of the LPD itself. Several studies have been conducted to examine how GCG influences financial performance. Based on research conducted by Aryastha (2017) states that GCG 
Principles have a positive effect on the financial performance of the LPD City of Denpasar. Likewise, Mulyawan (2017) states that GCG Principles have a positive effect on the performance of LPDs throughout Denpasar City. Some subsequent studies including Putri (2017), and Kusumasari et al (2017) get the same results, namely the principle of GCG has a positive effect on company performance. GCG is an important factor in determining company value and influencing company performance such as LPD. Although LPD can be said to be a business that has reach only in one customary village, it must be remembered that good governance can provide more benefits for a business organization.

$H_{1}$ : GCG has a positive effect on LPD Gianyar Regency Financial Performance.

Signal theory states that good quality companies will intentionally give signals to the market, thus the market is expected to be able to distinguish good and bad quality companies. According Jam'an (2008) Signaling Theory suggests about how a company should give signals to users of financial statements. This signal in the form of promotion or other information stating that the company is better than other companies. Several studies have been conducted to examine how the influence of bad credit on financial performance. Based on research conducted by Fauzzi (2018) which states that NPL has no significant effect on financial performance, Nurul (2018) who states that NPL has a negative effect on MSME financial performance and lending, as well as research conducted by Istiqomah (2018) found that NPL has a negative effect on BPR's financial performance in West Sumatra.

$\mathrm{H}_{2}$ : Bad Credit has a negative effect on LPD Financial Performance in Gianyar.

The Regency Teory contingency has a postulate that the effectiveness of an organization in overcoming environmental uncertainty are elements of various subsystems designed to meet the demands of interconnected environments which are the first and most well-known tool for explaining variations in organizational structure. One of them is organizational culture, in this case THK culture is one of the factors that support the successful implementation of GCG in an organization that will have an impact on improving organizational performance.

Several studies have been conducted to test how THK culture becomes a moderator for variables that affect organizational performance. In Mustikayani and Dwirandra (2016) THK culture is not able to moderate the effect of task complexity on auditor performance, but THK culture is able to moderate the effect of time pressure on auditor performance. Adiputra (2014) which states that THK culture can moderate the effect of task complexity on the internal auditor's performance at the Inspectorate Office in Bali Province. Puspitha and Sujana (2016) in their research produced an organizational culture that strengthens the influence of GCG principles on company performance based on balanced scorecard on BPR in Badung Regency.

The existence of THK culture in an LPD will support the creation of harmony in every business activity in it. THK culture in this case becomes complementary and provides understanding that everything must be carried out in a balanced manner. The application of good governance (GCG) in an LPD coupled with THK culture which is used as a foundation in every business activity carried out by employees, it is expected that the performance of the LPD can reach the maximum level which will be beneficial to all parties both agents in this case supervisors and employees and principals are all customers and indigenous village communities.

Performance.
Contingency theory is often referred to as situational theory because it proposes leadership that depends on situations where leadership will not occur in a social or environmental vacuum. In this case the situation in question is bad credit. Several studies have been conducted to examine how THK culture moderates the effect of bad credit on financial performance. Based on research conducted by Asep (2017) states that NPL has no effect on financial performance. Alfarizzi (2016) found that non-performing loans had no significant effect on performance. Likewise with Fauzzi (2018) getting the results that NPL does not have a significant effect on financial performance. 
One of the goals of the LPD is to strengthen the resilience of the Pekraman village in preserving the noble values of culture and culture. LPD organizations are inseparable from the problem of bad credit. The higher the number of bad loans, of course, will reduce financial performance. LPDs that operate are not solely engaged in the socio-economic sphere but there is a vision of preserving cultural life and the dimensions of human relations with God or what is called THK. With THK in the LPD environment it is expected that the negative effect of bad credit from financial performance can be weakened with the aim that the LPD's financial performance will improve.

$H_{4}$ : THK weakens the influence of Bad Credit on LPD Gianyar Regency Financial Performance.

\section{METHODS OF RESEARCH}

The population of this study is the LPD in Gianyar district. Based on data obtained from the Trustees of Gianyar Regency Rural Credit Institutions (PLPDK), there are 270 LPDs that are still operating in Gianyar Regency which will be selected using the Proportionate Stratified Random Sampling method. The analysis technique used is multiple linear regression analysis using Multiple Regression Analysis (MRA). Sources of data used in this study are primary data and secondary data. The methods of collecting data are using questionnaires and documentation.

\section{RESULTS AND DISCUSSION}

This study used 73 respondents consisting of 73 LPD chairpersons in each LPD spread across Gianyar Regency. Data were collected by distributing questionnaires directly to 73 LPDs in Gianyar Regency. The number of questionnaires distributed to LPDs in Gianyar Regency was 73 questionnaires and returned were 73 questionnaires (usability response rate $=100 \%$ ). Respondent characteristics data in this study include the level of education, age, and tenure.

The respondent characteristic data is described as follows: based on the level of education shows that the number of respondents was 73 people divided into several levels of education that is as many as 32 people $(43.83 \%)$ with a high school education, 2 people $(2.73 \%)$ with a diploma 3,36 people $(49.31 \%)$ had bachelor degree, and 3 people $(4.10 \%)$ had master degree. Based on the age level shows that the number of respondents as many as 73 people divided into several levels of age, as many as 28 people have ages $5-15$ years $(38.35 \%)$, as many as 34 people have ages $16-25$ years $(46.57 \%)$, as many as 7 people have age 26-35 years (9.58\%), and as many as 4 people have age $>35$ years $(5.47 \%)$. Based on the tenure shows that the number of respondents as many as 73 people divided into several tenure namely 28 people with $5-15$ years (38.35\%), 34 people with $16-25$ years $(46.57 \%)$, as many as 7 people with a term of $26-35$ years $(9.58 \%)$, and as many as 4 people with a term of $>35$ years $(5.47 \%)$.

Table 1 - Multiple Linear Regression Results

\begin{tabular}{llllll}
\hline \multirow{2}{*}{ Model } & \multicolumn{2}{l}{ Unstandardized Coefficients } & Standardized Coefficients & t & Sig. \\
\cline { 2 - 6 } & $\mathrm{B}$ & Std. Error & Beta & 4.525 & 0,000 \\
\hline (Constant) & 2.141 & 0,473 & & 2.531 & 0,014 \\
GCG & 0,013 & 0,005 & 0,179 & -10.727 & 0,000 \\
Bad Credit & $-0,598$ & 0,056 & $-0,671$ & 6.158 & 0,000 \\
THK & 0,060 & 0,010 & 0,417 & \\
\hline R Square & 0,875 & & & \\
Adjusted R Square & 0,765 & & & \\
F test & 75,033 & & & \\
Sig. & 0,000 & & & \\
\hline
\end{tabular}

Source: Data Proccesed, 2019.

Based on the results of multiple linear regression analysis as presented in Table 1, the structural equation is as follows:

$$
Y=2,141+0,013 X_{1}-0,598 X_{2}+0,060 M+\varepsilon
$$


The regression coefficient values of the GCG and THK variables are positive with a significance value of the t test less than 0.05 . This shows that the GCG and THK variables have a significant positive effect on the dependent variable. While the bad credit variable is negative with a significance value of $t$ test less than 0.05 . This shows that the bad credit variable has a significant negative effect on the dependent variable. Table 5.10 shows the value of $R$ Square in multiple linear regression analysis of 0.765 . This means that 76.5 percent of the performance obtained by the Gianyar Regency LPD is influenced by GCG, Bad Credit, and THK.

Moderated Regression Analysis. This model aims to determine whether the moderating variable is able to influence the relationship between the independent variable and the dependent variable. The results of the interaction test analysis using the SPSS program can be seen in Table 2.

Table 2 - Result of Moderated Regression Analysis

\begin{tabular}{|c|c|c|c|c|c|}
\hline \multirow{2}{*}{ Model } & \multicolumn{2}{|c|}{ Unstandardized Coefficients } & \multicolumn{2}{|l|}{ Standardized Coefficients } & \multirow{2}{*}{ Sig. } \\
\hline & $\overline{\mathrm{B}}$ & Std. Error & Beta & & \\
\hline (Constant) & 2.186 & 0,398 & & 5.487 & 0,000 \\
\hline GCG & 0,014 & 0,004 & 0,202 & 3.381 & 0,001 \\
\hline 1 Bad Credit & $-0,450$ & 0,058 & $-0,506$ & -7.707 & 0,000 \\
\hline 1 THK & 0,018 & 0,012 & 0,126 & 1.503 & 0,138 \\
\hline $\mathrm{X} 1 . \mathrm{M}$ & 0,069 & 0,019 & 0,300 & 3.523 & 0,001 \\
\hline X2.M & 0,002 & 0,000 & 0,189 & 3.456 & 0,001 \\
\hline$R \overline{\text { Square }}$ & 0,839 & & & & \\
\hline Adjusted R Square & 0,827 & & & & \\
\hline $\mathrm{F}$ test & 69,606 & & & & \\
\hline Sig. & 0,000 & & & & \\
\hline
\end{tabular}

Source: Data Proccesed, 2019.

Based on the results of the moderation regression analysis as presented in Table 2 , the structural equation is as follows:

$$
Y=2,186+0,014 X_{1}-0,450 X_{2}+0,018 M+0,069 X_{1} M+0,002 X_{2} M
$$

The regression coefficient values of the GCG and THK variables are positive with a significance value of the t test less than 0.05 . This shows that GCG and THK variables have a significant positive effect on the dependent variable in moderation testing. While the bad credit variable is negative with a significance value of $t$ test less than 0.05 Furthermore, the data shows the interaction variables X1.M and X2.M are positive with a significance value of $t$ test less than 0.05 .

The $F$ test results in Table 2 show that the significance value of $P$ value 0,000 is smaller than $\alpha=0.05$, this means that the model used in this study is feasible. This result gives the meaning that all independent variables namely GCG, bad credit, THK, interaction variables between GCG and THK, and interaction variables between bad credit and THK are able to predict or explain the phenomenon of performance in LPD in Gianyar. This means that the model can be used for further analysis or in other words the model can be used to project because the results of goodness of fit are good with a significance value of $P$ value 0,000 .

The results of the determination coefficient test in Table 2 show the amount of adjusted $R^{2}$ is 0.827 . This means that variations in performance can be significantly affected by GCG variables, bad loans, THK, interaction variables between GCG and THK, and interaction variables between bad loans and THK by 82.7 percent while the remaining 17.3 percent is explained by other factors.

The Hypothesis test is carried out to test the effect of each independent variable on the dependent variable. The testing criteria used are if $\mathrm{t}$ arithmetic, $<0.05$, then $\mathrm{Ha}$ is accepted and if $\mathrm{t}$ arithmetic $>0.05$, then $\mathrm{Ha}$ is rejected. The results of the analysis indicate that GCG has a positive effect on LPD financial performance in Gianyar Regency. This shows that the 
better implementation of GCG in LPD in the Regency of Gianyar, will encourage increased financial performance.

The analysis shows that bad credit has a negative effect on LPD financial performance in Gianyar Regency. This shows that the higher the non-performing loans obtained by the Gianyar Regency LPD, the lower the financial performance of the Gianyar Regency LPD. Vice versa, the lower the level of bad loans, the more impact on the performance of the LPD. The results of the moderation regression analysis show that THK is statistically able to moderate the effect of GCG on performance. This shows that there are interactions of THK and GCG in influencing performance. If LPDs in Gianyar Regency apply increasingly good GCG principles, and are strengthened by the application of a high THK culture, it will be able to influence the performance of LPD employees which will have an impact on the resulting performance. The results of the moderation regression analysis show that THK is statistically able to moderate the negative effect of bad credit on performance. This shows that there is an interaction between THK and bad credit in influencing performance. THK was unable to strengthen the negative effect of bad credit, but THK was able to weaken the effect of bad credit on financial performance. THK in moderating the effect of bad credit can be seen in the aspect of pawongan, namely human-human relations. Where the way to weaken bad credit is by the LPD to provide guidance to employees so that they come more or closer to customers in the hope that customers are more disciplined in paying credit. The higher the bad credit, the financial performance will decrease. Vice versa, the lower the level of bad loans, the financial performance will increase. With the implementation of THK culture, it is expected that the negative effect of bad credit and financial performance will be weakened. This is because the values born of THK's philosophy form the mental attitude and human resource behavior of the Hindu community in Bali that can deliver LPD towards better growth and performance (Gunawan: 2012).

\section{CONCLUSION AND SUGGESTIONS}

Based on the results of research on THK as a moderating effect of GCG and Bad Credit on LPD Financial Performance in Gianyar Regency, it can be concluded that GCG has a positive effect on LPD financial performance in Gianyar Regency. The results of this study indicate that the better application of GCG in the Gianyar Regency LPD, will encourage improved financial performance produced by the Gianyar Regency LPD.

Bad credit has a negative effect on LPD's financial performance in Gianyar Regency. The results of this study indicate that the higher the bad credit obtained by the LPD of the Gianyar Regency, the lower the financial performance of the LPD in the Gianyar Regency will decrease.

The results of the moderation regression analysis showed that THK strengthened the influence of GCG on financial performance in LPD of the Regency of Gianyar. This shows that there are interactions between THK and GCG in influencing financial performance. The test results indicate that LPDs in Gianyar Regency who apply GCG principles, and are strengthened by the application of a high THK culture, will be able to improve the performance of LPD employees.

The result of the moderation regression analysis shows that THK weakens the effect of bad credit on the financial performance of LPDs in Gianyar Regency. This shows that there are interactions between THK and bad credit in influencing financial performance. The test results indicate that with the implementation of THK, it will be able to weaken the negative effect of bad loans so that the performance of LPD employees is increasing.

Based on the results of the study, there are several suggestions that can be given for development and improvement. Considering the influence of GCG that can improve financial performance, it is expected that LPDs in Gianyar Regency will continue to apply GCG principles. With the application of this principle, it is hoped that in the future LPDs can improve their performance, although there is no clear and equal regulation governing the application of GCG principles in LPD business processes. In addition, it is also important to remember that besides applying GCG principles, there are several supporting factors such 
as THK Culture. The existence of THK Culture has indeed become a foundation in all business processes carried out in an LPD.

Based on the results of the study, it is said that bad loans negatively affect financial performance, the LPD is expected to always apply the THK culture. With the THK culture, the company is expected to reduce the amount of bad credit so that the LPD's performance always goes in a good direction by producing good performance, so that the LPD will be able to sustain the economy of Balinese citizens in the local village.

For further research, it is expected to expand research objects that are outside of Gianyar Regency in order to complete and perfect all research LPDs in the Province of Bali with sample selection based on LPD issues such as LPD with the health category or LPD that are less healthy.

GCG and THK measurements are still measured using a questionnaire; this is due to the lack of measurement of this variable by default issued by the LPLPD. If later it already exists, this will make the assessment of the good coporate governance variable clearer and can minimize the bias response that can occur.

\section{REFERENCES}

1. Abdi, Tri. A. (2019). Pengaruh Penerapan GCG and Budaya Tri Hita Karana Pada Kinerja Keuangan LPD Di Kabupaten Jembrana. E-Jurnal Akuntansi. Universitas Udayana Vol.27.1.April (2019): 90-118.

2. Adi Sukayana. (2019). Budaya Tri Hita Karana and Komitmen Organisasi Sebagai Pemoderasi Pengaruh Partisipasi Penganggaran Pada Budgetary Slack. Tesis. Universitas Udayana.

3. Adnyana, P. (2016). Tri Hita Karana dalam Agama Hindu. http://babadbali.com/canangsari/2016/tri-hita-karana-dalam-agama-hindu/ diunduh tanggal 21 Juli 2016.

4. Arya Mulyawan. (2017). Budaya Tri Hita Karana Sebagai Pemoderasi Pengaruh Prinsip Good Corporate Governance Pada Kinerja Lembaga Perkreditan Desa (Lpd) (Studi Di Lpd Se-Kota Denpasar. Tesis. Universitas Udayana.

5. Budiman, A., \& Fadillah, A. R. (2017). Pengaruh rasio kredit macet and likuiditas terhadap kinerja keuangan bank perkreditan rakyat. Jurnal Ekonomi Manajemen, 3(2), $120-128$.

6. Dabor, Alexander Olawumi, David T. Isiavwe, Muribav Akintunde Ajagbe and Adunola Oluremi Oke. 2015. Impact of Corporate Governance on Firm's Performance. International Journal of Economics, Commerce and Management. Vol. 3. No. 6. pp: 634753.

7. Desy Mustikayani. (2016). Budaya Tri Hita Karana Sebagai Pemoderasi Kompleksitas Tugas and Tekanan Waktu Terhadap Kinerja Auditor. E-Jurnal Akuntansi Universitas Udayana. Vol.16.2. Agustus (2016): 1544-1573. Fakultas Ekonomi and Bisnis Universitas Udayana (Unud).

8. Dian Kusumasari. (2017). Pengaruh Penerapan Prinsip-Prinsip Good Corporate Governance, Komitmen Organisasi, Gaya Kepemimpinan and Pengawasan Internal Terhadap Kinerja Lembaga Perkreditan Desa (Studi Empiris Pada Lpd Kecamatan Ubud Kabupaten Gianyar). e-Journal Universitas Pendidikan Ganesha (Volume 7 No 1 Tahun 2017)

9. Dwi Pura, Zilal Hamzah, Dini Hariyanti. (2018). Analisis Pengaruh Good Corporate Governance Terhadap Kinerja Keuangan Perbankan Yang Terdaftar Di Bursa Efek Indonesia Periode 2014-2017. ISSN (P): 2460 - 8696. Economics Magister Programme, FEB, Universitas Trisakti, Indonesia.

10. Dewi, K. K., \& Dwijaputri, I. M. A. (2014). Pengaruh Penerapan Prinsip-Prinsip Gcg Pada Kinerja Keuangan Lembaga Perkreditan Desa Kabupaten Gianyar Bali. E-Jurnal Akuntansi Universitas Udayana 7.3 (2014): 559-573, 3(Issn: 2302-8556), 559-573.

11. Dewi, S. R., \& Ratnadi, N. M. D. (2018). Pengaruh Jumlah Nasabah Kredit and Kredit Yang Disalurkan Pada Profitabilitas Dengan Npl Sebagai Pemoderasi. EJurnalAkuntansi, 22, 1335. 
12. Eko Sunarwan. (2015). Pengaruh GCG Terhadap Kinerja Keuangan Perbankan Syariah. Program Studi Muamalat (Ekonomi Islam) Fakultas Syariah and Hukum Universitas Islam Negeri Syarif Hidayatullah Jakarta.

13. Eky, Kartika, Yuli. (2018). Pengaruh Good Corporate Governance Terhadap Kinerja Keuangan Pada Perusahaan Manufaktur Industri Real Estate and Property Di Bei Periode 2014-2016. Fakultas Ekonomi Program Studi Akuntansi Universitas Islam Batik Surakarta

14. Fatimah, I. N., \& Kusumah, W. R. (2018). The Impact of Ability To Channel Funds And Non-Performing Loan On Profitability Of Listed Banks On Indonesia Stock Exchange. International Journal Of Education And Research, 6(12), 55-64.

15. Gunawan, K. (2011). Peran Falsafah Tri Hita Karana Bagi Pertumbuhan and Kinerja Lembaga Perkreditan Desa (Lpd) Di Bali. Jurnal Analisis Manajemen, 5(2), 23-36.

16. Kasmir. (2000). Manajemen Perbankan. Edisi Revisi. Jakarta: PT Raja Grafindo Persada.

17. Kasmir. (2002). Dasar - Dasar Perbankan. Edisi Revisi. Jakarta: PT Raja Grafindo Persada.

18. Kautsar, A. and Kusumaningrum, T.M. (2015). Analisis Pengaruh Good Corporate Governance Terhadap Kinerja Perusahaan yang Dimediasi Struktur Modal Pada Perusahaan Pertambangan yang Listed di BEI 2009-2012. Journal of Research in Economics and Management. Vol. 15. No. 1. pp: 29-75.

19. Krishna Aryastha Mahendrayasa. (2017). Pengaruh Prinsip-Prinsip Good Corporate Governance Terhadap Kinerja Keuangan Lembaga Perkreditan Desa (Lpd) Di Kota Denpasar ISSN: 2302-8556 E-Jurnal Akuntansi Universitas Udayana Vol.21.2. November (2017).

20. Krismaya Dewi. (2014). Pengaruh Penerapan Prinsip-Prinsip Gcg Pada Kinerja Keuangan Lembaga Perkreditan Desa Kabupaten Gianyar Bali. E-Jurnal Akuntansi Universitas Udayana 7.3 (2014).

21. (Kusuma, 2018)Akbar, M. T., P., M., \& Djazuli, A. (2018). Pengaruh Kredit Macet Terhadap Profitabilitas Melalui Kecukupan Modal, Biaya and Pendapatan Operasional. Jurnal Bisnis and Manajemen, 5(1), 79-91.

22. Kautsar, M. Al, \& Fadjar, A. (2012). Pengaruh Struktur Kepemilikan and Good Corporate Governance Terhadap Kinerja Keuangan Bumn. Seminar Nasional Akuntansi \& Bisnis, (Issn-2252-3936), 99-106.

23. Kusumasari, P. D., Sinarwati, N. K., \& Yuniarta, G. A. (2017). Pengaruh Penerapan Prinsip-Prinsip Good Corporate Governance, Komitmen Organisasi, Gaya Kepemimpinan and Pengawasan Internal Terhadap Kinerja Lembaga Perkreditan Desa (Studi Empiris Pada Lpd Kecamatan Ubud Kabupaten Gianyar). Jurnal IImiah Mahasiswa Akutansi Undiksha, 7(1).

24. Lexy J. Moleong, M.A. (1988). Metodologi Penelitian Kualitatif. Edisi Revisi. Bandung: PT Remaja Rosdakarya.

25. Lidya Ayu Amanda. (2019). Pengaruh Budaya Organisasi, Komitmen and Akuntabilitas Pada Kinerja Lembaga Perkreditan Desa. E-Jurnal Akuntansi Universitas Udayana Vol.27.3.Juni (2019).

26. Made, N., Surya, S., \& Suartana, I. W. (N.D.). Tri Hita Karana Culture As A Moderate Influence Of The Love Of Money On Ethical Perception Of Fraudulent Accounting Practices. 4531, 124-138.

27. Mahaendrayasa and Putri. (2017). Pengaruh Prinsip-Prinsip Good Corporate Governance Terhadap Kinerja Keuangan Lembaga Perkreditan Desa (Lpd) Di Kota Denpasar. E-Jurnal Akuntansi Universitas Udayana, 21(2), 970-995.

28. Mery Yandani. (2019). Pengaruh Penerapan Prinsip-Prinsip Good Corporate Governance and Budaya Tri Hita Karana Terhadap Kinerja Manajerial Lembaga Perkreditan Desa (Lpd) Pakraman Padangsambian. Jurnal Ilmiah Akuntansi \& Bisnis. Volume 4, No. 1, Juni 2019. Universitas Pendidikan Nasional (Undiknas) Denpasar.

29. Nasional, S., Devi, H. P., Widiasmara, A., \& Kredit, J. P. (2016). Pengaruh Npl Roa Terhadap Kredit Bank Umum Dengan Sbi Sebagai Pemoderasi 1. 76-82.

30. Pengantar, K. (N.D.). Budaya Organisasi 01.Pdf. 
31. Pengaruh Good Corporate Governance Terhadap Kinerja Keuangan Pada Perbankan Syari'ah Indonesia. (2018). 5(Issn 2339-243).

32. Puspitha, M.Y. and Sujana, I K.. (2016). Budaya Organisasi Pemoderasi Pengaruh Prinsih Good Corporate Governance pada Kinerja Perusahaan Berbasis Balanced Scorecard. E-Jurnal Akuntansi Universitas Udayana. Vol. 14. No. 3. pp: 1978-2012.

33. Pradana Adiputra. (2014). Budaya Tri Hita Karana Sebagai Pemoderasi Pengaruh Locus Of Control and Kompleksitas Tugas Terhadap Kinerja Internal Auditor (Studi Pada Kantor Inspektorat Di Provinsi Bali). Artikel. Universitas Indonesia.

34. Pradiantama Risda. (2018). Pengaruh Perputaran Modal Kerja and Pertumbuhan Koperasi Pada Profitabilitas Dengan NPL Sebagai Pemoderasi. Skripsi. Universitas Udayana.

35. Putri, IG.A.M.A.D. (2012). Peranan Good Corporate Governance and Budaya terhadap Kinerja Organisasi. Audi Jurnal Akuntansi \& Bisnis. Vol. 7. No. 2. pp: 193-204.

36. Prena, G. Das, Evitasari, A., Tri, B., Karana, H., Pemoderasi, S., External, P., \& Belakang, L. (2019). Budaya Tri Hita Karana Sebagai Pemoderasi Pengaruh External Locus Of Control Terhadap Kinerja Auditor: Studi Pada Kantor Akuntan Publik SeProvinsi Bali. 4(1), 38-49.

37. Rastiana Dewi. (2017). Pengaruh Penerapan Gcg and Ukuran Perusahaan Terhadap Kinerja Keuangan Perbankan Di Bei Periode 2013-2016. E-Jurnal Akuntansi Universitas Udayana Vol.21.1. Oktober (2017).

38. Rahmatika, N., Kirmizi, and Agus, R. (2015). Pengaruh Penerapan Prinsip-Prinsip Good Corporate Governance Terhadap Kinerja Keuangan Perusahaan (Studi pada PT Angkasa Pura II). Jurnal Akuntansi (Media Riset Akuntansi and Keuangan).Vol. 3. No. 2. pp: 148-156.

39. Renders, Annelies, Gaerumynck, A. and Sercu, P. (2010). Corporate Governance Ratings and Company Performance: A Cross-European Study. Corporate Governance: An International Review. Vol. 18. No. 2. pp: 87-106.

40. Revita, M. L. D. E. (2018). Pengaruh Gcg, Car, Ldr Terhadap Kinerja Keuangan Serta Harga Saham Perbankan. Jurnal Ecodemica, 2(2), 156-176.

41. Salsabila Sarafina. (2017). Pengaruh Good Corporate Governance Terhadap Kinerja Keuangan and Nilai Perusahaan. Jurnal Administrasi Bisnis (Jab)|Vol. 50 No. 3 September 2017.

42. Sarafina, S., \& Saifi, M. (2017). Pengaruh Good Corporate Governance Terhadap Kinerja Keuangan and Nilai Perusahaan ( Studi Pada Badan Usaha Milik Negara ( Bumn ) Yang Terdaftar Di Bursa Efek Indonesia Periode 2012-2015). Jurnal Administrasi Bisnis (Jab), 50(3), 108-117.

43. Sarjana, P., Jenis, A., Manajemen, D., Ekonomi, F., \& Manajemen, D. A. N. (2014). Tesia,Pengaruh penerapan konsep Good Corporate Governance Terhadap Kinerja NonKeuangan Di Kantor Pusat Pt Asuransi Jasa Indonesia.

44. Stefani, M. (2017). Munich Personal RePEc Archive Analysis The Influence of Good Corporate Governance and Capital Structure to Firm Value With Financial Performance as Intervening Variable ( Study at Manufacturing Companies that Listed at Indonesia Stock Exchange ).

45. Sintya Surya D. (2018). Budaya Tri Hita Karana Sebagai Pemoderasi Pengaruh Love Of Money Pada Persepsi Etis Kecurangan Akuntansi Kepala LPD se Kota Denpadar. Tesis. Universitas Udayana.

46. Solimun, (2010). Analisis Variabel Moderasi and Mediasi. Malang: Program Studi Statistika FMIPA-UB.

47. Sudirman. (2013). Manajemen Perbankan. Edisi Pertama. Denpasar: Kencana Prenada Media Group.

48. Sugiarto Eko.(2015). Menyusun Proposal, Penelitian Kualitatif, Skripsi and Tesis Cetakan Pertama. Yogyakarta: Suaka Media.

49. Sugiyono. (2018). Metode Penelitian ManajemenPendidikan. Cetakan ke 6. Bandung: Alfabeta. 
50. Surya Dewi.(2018). Tri Hita Karana Culture as a Moderate Influence of the Love of Money on Ethical Perception of Fraudulent Accounting Practices. International Journal of Sciences: Basic and Applied Research (IJSBAR) (2018) Volume 40, No 2, pp 124-138. Faculty of Economics and Business, University of Udayana.

51. Suardikha, I. M. S. (2013). Pengaruh Budaya Tri Hita Karana Terhadap Penggunaan Sistem Informasi Akuntansi Dimediasi Persepsi Kegunaan and Persepsi Kemudahan Penggunaan. Jurnal Akuntansi and Keuangan Indonesia, 10(1), 102-128. Https://Doi.Org/10.21002/Jaki.2013.06.

52. Tonggina Pakpahan. (2017). Pengaruh Good Corporate Governance Terhadap Kinerja Keuangan Studi Kasus Pada Perusahaan Perbankan Yang Terdaftar Di Bursa Efek Indonesia Tahun 2012-2015. Eissn: 2540-9220 Volume:2 Online No.1 2017. Universitas Kristen Jakarta.

53. Triadhi, N. A., Utama, M. S., Kembar, M., Budhi, S., Bagus, I., \& Purbadharmaja, P. (2018). An Analysis Of Culture Influence Of The Trihita Karana, Community Empowerment, The Entrepreneurship Orientation, And Fishermen Institution With Respect To The Welfare Of Fishermen On The Serangan Island In Bali. 9(5), 82-103. Https://Doi.Org/10.9790/5933-09050382103.

54. Utama Suyana. 2016. "Aplikasi Analisis Kuantitatif". Denpasar. Fakultas Ekonomi Universitas Udayana.

55. Widya Kirana. 2019. Pengaruh Independensi Auditor, Pemahaman Good Governance and Self Efficacy Terhadap Kinerja Auditor Pada KAP Bali. E-Jurnal Akuntansi Universitas Udayana Vol.27.3.Juni (2019). 